\title{
POTENSI PENGGUNAAN PROTEIN REKOMBINAN FLIC (FLAGELLIN) UNTUK MENINGKATKAN IMUNOGENITAS VAKSIN DNAANTI KARIES GIGI (Kajian Pustaka)
}

\author{
Sinta Deviyanti* \\ *Bagian Konservasi FKG UPDM(B) Jakarta
}

\begin{abstract}
ABSTRAK
Karies gigi merupakan penyakit infeksi kronis yang menyebabkan pelarutan lokal dan kerusakan jaringan kalsifikasi gigi oleh aktivitas fermentasi dari bakteri terhadap karbohidrat yang dikonsumsi. Streptococcus mutans dianggap sebagai patogen utama pada karies gigi. Berbagai strategi pencegahan karies telah digunakan seperti penyuluhan kesehatan rongga mulut, kontrol plak secara mekanik dan kimia, aplikasi pit dan fissure sealant, penggunaan fluoride. Meskipun demikian, prevalensi karies gigi masih tetap tinggi diseluruh dunia. Upaya pencegahan karies terkini adalah melalui pengembangan vaksin DNA anti karies gigi. Vaksin merupakan bahan kekebalan tubuh biologis yang dirancang untuk menghasilkan perlindungan spesifik terhadap mikroorganisme patogen. Vaksin menstimulasi produksi antibodi pelindung dan mekanisme imun lainnya. Namun imunogenisitas yang rendah dari vaksin DNA, masih menjadi tantangan. Para peneliti menggunakan protein rekombinan FliC (flagellin) yang berasal dari Salmonela sebagai suatu ajuvan mukosa dan aktivator imun yang kuat untuk meningkatkan respon IgG (Imunoglobulin G) serum dan IgA (Imunoglobulin A) saliva. Peningkatan respon spesifik IgG serum dan IgA saliva oleh vaksin DNA yang dikombinasi dengan protein rekombinan FliC pada tikus melalui vaksinasi karies gigi intra nasal, memiliki keterkaitan dengan penghambatan kolonisasi Streptococcus mutans di permukaan gigi dan pengurangan lesi karies secara bermakna.
\end{abstract}

Kata kunci : karies gigi, vaksin DNA anti karies, protein rekombinan FliC,Streptococcus mutans, IgA saliva

\begin{abstract}
Dental caries is a chronic, infectious disease that results in localized dissolution and destruction of the calcified tissue on the tooth by bacterial fermentation activity of dietary carbohydrates. Streptococcus mutans has been considered a primary pathogen of dental caries.Various caries preventive strategies are use such as oral health education, chemical and mechanical control of plaque, application of pit and fissure sealants, used of fluorides. Nevertheless, dental caries maintains a high prevalence worldwide The latest approach for caries prevention is through the development of anticaries DNA vaccine. Vaccines are an immune-biological substance designed to produce specific protection against microorganism pathogen. It stimulates the production of a protective antibody and other immune mechanisms. However, challenges remain because of the low immunogenicity of DNA vaccines. To increase the immunogenicity of anti caries DNA vaccines, researchers have used recombinant protein FliC (flagellin) derived from Salmonella as a mucosal adjuvant and potent immune activator for enhancing serum IgG (Immunoglobulin $\mathrm{G}$ ) and salivary IgA(Immunoglobilin A) responses. Enhanced DNA vaccines combined with recombinant protein FliC-spesific IgA responses in saliva of rats by intranasal vaccination were associated with the inhibition of Streptococcus mutans colonization of tooth surfaces and significant fewer caries lesions.
\end{abstract}

Key words : dental caries, anti-caries DNA vaccine, recombinant protein FliC, Streptococcus mutans,salivary IgA

\section{PENDAHULUAN}

K aries gigi merupakan salah satu penyakit infeksi kronis yang paling umum diderita manusia di seluruh dunia dan menyebabkan demineralisasi jaringan mineralisasi gigi dan kerusakan struktur gigi akibat aktivitas fermentasi karbohidrat terutama oleh bakteri Streptococcus mutans (S.mutans) dalam plak gigi (biofilm). ${ }^{1,2,3,4}$ Penyakit ini dapat berkembang secara perlahan pada individu, baik pada anak-anak, remaja maupun dewasa. Prevalensi karies gigi di berbagai negara masih tergolong tinggi dan bervariasi hingga mencapai lebih dari 90\%, meskipun telah dilakukan berbagai upaya pencegahan., ${ }^{1,5,6}$

Vaksinasi karies gigi melalui penggunaan vaksin DNA anti karies gigi yang memiliki efek terapeutik, kini telah dikembangkan sebagai salah satu upaya alternatif 
pencegahan karies gigi. Vaksinasi secara aktif merupakan prosedur untuk meningkatkan derajat imunitas (kekebalan) protektif dengan menginduksi respon memori terhadap patogen maupun toksin tertentu dengan menggunakan preparat antigen non virulen atau non toksik. ${ }^{7}$ Vaksin DNA anti karies gigi yang digunakan untuk vaksinasi karies gigi, memiliki beberapa keunggulan dibandingkan vaksin tradisional, diantaranya mampu menginduksi respon imun humoral dan selular dalam tubuh manusia. Namun, vaksin DNA anti karies gigi ini juga masih memiliki kendala berupa sifat imunogenitasnya (kemampuan untuk menginduksi respon imun) yang rendah. Para peneliti kini telah memanfaatkan protein rekombinan FliC (flagellin) dari Salmonella enterica sebagai suatu ajuvan (bahan bukan antigen yang ditambahkan ke dalam vaksin untuk meningkatkan respon imun) mukosa yang bersifat imunomodulator atau aktivator imun poten untuk meningkatkan sifat imunogenitas dari vaksin DNA anti karies gigi. ${ }^{7,8}$ Penggunaan protein rekombinan FliC (flagellin) sebagai suatu ajuvan mukosa pada vaksin DNA anti karies gigi, terbukti dapat meningkatkan sifat imunogenitas dari vaksin DNA anti karies gigi sehingga mampu menghambat kolonisasi bakteri S.mutans di permukaan gigi hewan percobaan tikus serta menghambat pembentukan karies lebih lanjut. ${ }^{8}$

Tujuan penulisan makalah ini adalah untuk memberi informasi dan mengkaji tentang potensi penggunaan protein rekombinan FliC (flagellin) untuk meningkatkan imunogenitas vaksin DNA anti karies gigi. Manfaat penulisan makalah ini diharapkan dapat memperluas wawasan dan menjadi dasar pengetahuan pembaca khususnya praktisi di bidang kedokteran gigi, untuk memilih dan mengembangkan vaksin anti karies gigi yang lebih efektif dan aman sebagai salah satu upaya alternatif pencegahan karies gigi.

\section{KAJIAN PUSTAKA}

\section{Definisi, Etiologi dan Strategi Pencegahan Karies Gigi}

Karies gigi secara klinis didefinisikan sebagai proses demineralisasi atau pelarutan komponen mineral (inorganik) dari jaringan gigi secara progresif akibat aktivitas fermentasi karbohidrat oleh bakteri penghasil asam di dalam plak gigi (biofilm) hingga menyebabkan kerusakan struktur (bahan organik) gigi dan lebih lanjut menyebabkan terbentuknya lubang (kavitas). ${ }^{1,2,4}$ Etiologi karies gigi bersifat multifaktorial, melibatkan permukaan gigi yang rentan, aliran saliva, bakteri dalam plak gigi, konsumsi karbohidrat yang dapat difermentasi dan sejumlah faktor lingkungan lainnya., ${ }^{2,9}$ Aktivitas fermentasi karbohidrat (misalnya sukrosa) terutama oleh bakteri Streptococcus mutans dalam plak gigi, akan menyebabkan penurunan $\mathrm{pH}$ cairan plak gigi dari $\mathrm{pH} 7.0$ menjadi pH 5.0 yang bersifat asam. Kondisi pH asam dari plak gigi tersebut akan menyebabkan komponen inorganik dari mineral di permukaan terluar gigi (email) yang tersusun dari kristal hidroksiapatit menjadi tidak stabil dan mengalami pelarutan atau demineralisasi.
Secara makroskopis, gambaran awal karies gigi sebagai proses demineralisasi yang terjadi di bagian email dari jaringan gigi, akan terlihat sebagai daerah putih kapur (opaque) yang disebut sebagai white spot. ${ }^{1}$

Bila tidak ada lagi karbohidrat yang dikonsumsi, pH asam dari plak gigi akan kembali normal dalam waktu 30-45 menit. Kondisi pelarutan mineral struktur gigi atau demineralisasi selanjutnya akan diperbaiki oleh ion-ion mineral dari saliva yang disebut sebagai proses remineralisasi. Namun bila keseimbangan antara demineralisasi dengan remineralisasi yang dinamis ini lebih cenderung kepada demineralisasi maka secara klinis akan terjadi karies gigi. ${ }^{1}$

Upaya pencegahan karies gigi dapat dilakukan melalui berbagai cara, diantaranya melalui pemberian edukasi tentang kesehatan atau kebersihan rongga mulut, pengontrolan plak gigi secara mekanik (menggunakan sikat gigi) dan secara kimia (menggunakan obat kumur), aplikasi pit dan fissure sealants, penggunaan fluoride dan sebagainya. ${ }^{5}$ Walaupun telah dilakukan berbagai upaya tersebut, prevalensi karies gigi masih cukup tinggi, dapat mencapai lebih dari 90\% di berbagai negara berkembang maupun negara industri serta menghabiskan biaya besar untuk perawatannya. ${ }^{6}$ Hal inilah yang mendorong dikembangkannya vaksin anti karies gigi sebagai strategi baru untuk mencegah karies gigi yang aplikasinya ditujukan untuk kesehatan masyarakat terutama pada kondisi tidak dapat dilakukannya perawatan kesehatan rongga mulut secara berkala. ${ }^{5}$

\section{Definisi Vaksin, Vaksinasi Secara Umum dan Vaksinasi Karies Gigi}

Vaksin adalah suatu suspensi mikroorganisme atau substansi mikroorganisme yang digunakan untuk menginduksi sistem imunitas melalui prosedur imunisasi. Imunisasi atau sering disebut juga dengan vaksinasi, secara umum merupakan suatu cara untuk meningkatkan imunitas (kekebalan) seseorang baik secara aktif maupun pasif, terhadap invasi mikroorganisme patogen atau toksin. ${ }^{10}$ Pemberian vaksin pada prosedur vaksinasi secara aktif, bertujuan meningkatkan derajat imunitas (kekebalan) protektif suatu individu, dilakukan dengan cara menginduksi respon memori tubuh terhadap patogen maupun toksin tertentu dengan menggunakan preparat antigen non virulen atau non toksik. ${ }^{7}$ Vaksinasi secara aktif dilakukan melalui pemberian vaksin berupa suspensi, substansi atau toksin mikroorganisme yang sudah dimatikan atau dilemahkan untuk merangsang agar tubuh memproduksi antibodi sendiri. Antibodi sebagai kelompok protein imunoglobulin (IgG , IgA , IgM, IgE ,IgD), merupakan komponen utama dari respon imun humoral pada tubuh manusia. Vaksinasi secara pasif dilakukan melalui pemberian vaksin yang mengandung sejumlah antibodi sehingga kadar antibodi dalam tubuh menjadi meningkat. ${ }^{2,7,10}$

Vaksinasi karies gigi merupakan upaya yang dilakukan untuk membentuk kekebalan dan 
perlindungan terhadap karies gigi . Vaksinasi karies gigi secara aktif dikembangkan dengan menggunakan protein yang terdapat di permukaan bakteri rongga mulut terutama S.mutans (sebagai antigen) untuk menginduksi tubuh manusia agar memproduksi antibodi terhadap antigen alamiah tersebut. Komponen antigen dari S.mutans dalam vaksin anti karies gigi yang berfungsi sebagai aktivator dari respon imun antara lain yaitu adhesin ( $P a c$ atau $P i$ atau AgI/II), GTF (Glucocyltransferases), GBP (Glucan Binding Protein) dan dextranases. ${ }^{4,5,9}$

\section{Definisi, Struktur, Produksi, Mekanisme Kerja dan Formulasi Vaksin DNA}

Vaksin telah lama dikenal sebagai substansi yang digunakan untuk memperoleh respon imun terhadap mikroorganisme patogen. Vaksin konvensional generasi pertama yang mengandung mikroorganisme hidup yang telah dilemahkan dan vaksin generasi kedua yang mengandung mikroorganisme yang telah dimatikan serta vaksin rekombinan (sub unit) sebagai vaksin generasi ketiga yang mengandung fragmen antigenik dari suatu mikroorganisme untuk merangsang respon imun, dalam penggunaannya masih memiliki beberapa kelemahan. Vaksin generasi pertama memiliki resiko dapat bermutasi menjadi virulen sehingga menimbulkan efek yang tidak diinginkan dan biasanya tidak dianjurkan diberikan pada individu yang mengalami imunokompromais Vaksin generasi kedua dalam penggunaannya sering mengalami kegagalan atau tidak menimbulkan respon imun tubuh. Sedangkan vaksin generasi ketiga yang dikenal sebagai vaksin rekombinan atau sub unit, hanya dapat menimbulkan respon imun humoral dan tidak dapat menimbulkan respon imun seluler. ${ }^{10}$

Terkait dengan masih dijumpainya kelemahan dari ketiga generasi vaksin tersebut diatas, kini dikembangkan vaksin generasi keempat melalui transfer DNA (Deoxy Ribonucleic Acid) plasmid yang dikenal sebagai vaksin DNA (Deoxyribose Nucleic Acid). Vaksin DNA dibuat dengan merekayasa molekul antigen mikroba tertentu melalui teknologi DNA. Vaksin DNA terdiri dari plasmid bakteri yang mengandung DNA yang menyandi protein antigen, dapat memicu imunitas humoral maupun selular. Melalui rekayasa genetik, segmen dari bahan herediter atau DNA dari suatu organisme, dapat dikombinasi dengan gen organisme kedua. Organisme yang relatif sederhana seperti bakteri atau jamur, dapat diinduksi untuk memproduksi protein yang berasal dari patogen atau agen infeksi (misalnya virus) untuk digunakan dalam vaksin. ${ }^{7}$ Vaksin DNA dapat mengandung satu gen atau lebih yang diisolasi dari virus dan mengkode ekspresi dari protein inti virus atau protein selubung virus. Sel hospes yang divaksinasi dengan vaksin DNA, akan menggunakan DNA yang terdapat pada vaksin untuk memproduksi protein virus yang bersifat antigenik. ${ }^{10}$ Uji klinik penggunaan vaksin DNA telah dilakukan pada hewan percobaan maupun manusia terhadap berbagai jenis penyakit infeksi seperti malaria, virus dengue, virus influenza, virus HIV, virus Ebola, SARS corona virus dan virus hepatitits B. ${ }^{10}$ Vaksin DNA di bidang kedokteran gigi saat ini juga telah dikembangkan untuk menghambat infeksi yang disebabkan oleh bakteri S.mutans sebagai bakteri utama penyebab karies gigi. ${ }^{11}$

Vaksin DNA memiliki struktur yang terdiri dari dua unit utama. Unit pertama yaitu unit propagasi plasmid yang terdiri dari fragmen DNA untuk replikasi dan marka seleksi, berfungsi sebagai pengendali replikasi dan perbanyakan (pembiakan) plasmid DNA secara in vitro di dalam sel bakteri sesuai dengan jumlah dan volume yang diinginkan pada saat diproduksi. Sedangkan unit kedua, terdiri terdiri dari fragmen DNA yang mengandung gen vaksin yang telah dikloning ke dalam plasmid DNA dengan harapan gen vaksin ini dapat mengekspresikan (menjelmakan) protein asing di dalam sel hospes. ${ }^{10}$

Produksi vaksin DNA secara in vitro biasanya menggunakan bakteri Escherichia coli. Plasmid DNA ditransformasi ke dalam sel bakteri, kemudian dilakukan seleksi sel transforman Escherichia coli yang mengandung plasmid DNA. Klon Escherichia coli yang membawa plasmid DNA ini kemudian dibiakkan dalam media yang sesuai dalam skala industri, kemudian plasmid diisolasi, dimurnikan dan diformulasi menjadi vaksin DNA. ${ }^{10}$

Setelah vaksin DNA disuntikkan ke dalam jaringan tubuh, maka unit sintesis vaksin akan bekerja di dalam sel hospes atau sel manusia. Mekanisme kerjanya melalui replikasi plasmid DNA secara otonom dan produksi protein asing atau antigen yang dikode oleh gen vaksin tersebut di dalam tubuh hospes untuk menstimulasi respon imun tubuh sehingga menghasilkan kekebalan terhadap serangan mikroorganisme spesifik. Protein asing atau antigen yang di kode oleh plasmid DNA dalam vaksin, akan menstimulasi respon imun humoral tubuh hospes sehingga sel limfosit B memproduksi antibodi terhadap antigen tersebut. Sel yang mengandung antigen asing tersebut kemudian juga dapat bersifat sebagai sel penyaji antigen atau APC (Antigen Presenting Cells) yang menstimuli respon imun selular oleh limfosit $\mathrm{T}$ melalui jalur major histocompatibility complex (MHC). ${ }^{2,10}$

Salah satu faktor penting dalam meningkatkan potensi vaksin DNA untuk meningkatkan respon imun adalah formulasi dan ajuvan. Ajuvan adalah bahan bukan antigen yang ditambahkan ke dalam vaksin untuk meningkatkan respon imun termasuk mengaktivasi sel limfosit T melalui peningkatan akumulasi APC ditempat pajanan antigen dan ekspresi kostimulator serta sitokin oleh APC. ${ }^{7}$ Penggunaan ajuvan sebagai suatu imunomodulator dalam vaksin DNA, diperlukan untuk meningkatkan imunogenitas vaksin DNA. ${ }^{7,12}$ Respon imun ditandai oleh adanya induksi sel limfosit B untuk memproduksi Ig (imunoglobulin) dan adanya aktivasi sel limfosit T yang melepas sitokin. Ajuvan yang diikat 
oleh antigen dalam vaksin akan membantu antigen tetap berada di lokasi penghantaran vaksin serta membantu membawa antigen ke kelenjar getah bening sebagai tempat terjadinya respon imun. ${ }^{7}$ Beberapa jenis ajuvan yang digunakan untuk vaksin DNA antara lain polylactide (PLG), poloxamers dan vaxfectin. ${ }^{10}$

\section{Efektifitas Vaksin DNA Anti Karies Gigi yang Dikombinasi dengan Protein Rekombinan FliC (Flagellin)}

Vaksinasi karies gigi melalui jalur intra nasal pada tikus menggunakan $p G J A-P / V A X$ sebagai vaksin DNA anti karies gigi telah terbukti mampu menginduksi respon antibodi IgA saliva setidaknya selama lebih dari enam bulan. ${ }^{13}$ Penelitian lainnya juga telah memperlihatkan kemampuan $p G J A-P / V A X$ sebagai vaksin DNA anti karies gigi dalam menghambat infeksi yang disebabkan oleh bakteri S.mutans. ${ }^{11}$ Penelitian lain selanjutnya juga telah membuktikan kemampuan $p G J A-$ $P / V A X$ sebagai vaksin anti karies gigi dalam memberi perlindungan pejamu (host) terhadap karies gigi ${ }^{14}$. Meskipun demikian, vaksin DNA anti karies gigi juga masih memiliki kelemahan dalam hal imunogenitasnya yang rendah sehingga para peneliti masih terus berupaya meningkatkan imunogenitas vaksin DNA karies gigi antara lain dengan jalur penghantaran vaksin DNA melalui mukosa atau merancang jenis target baru untuk vaksin DNA anti karies gigi. ${ }^{8,13}$

Terkait masih dijumpainya kelemahan pada vaksin DNA anti karies tersebut, penelitian Shi W,dkk pada tahun 2012 telah menggunakan protein rekombinan FliC (Flagellin) sebagai ajuvan mukosa untuk $p G J A-$ $P / V A X$ (vaksin DNA anti karies gigi) melalui jalur vaksinasi intra nasal. Protein rekombinan tersebut dibuat menggunakan gen FliC dari Salmonella enterica yang diamplifikasi dengan teknik PCR (Polymerase Chain Reaction) dan di kloning ke dalam vektor plasmid. Efek protein rekombinan FliC pada respon antibodi (dalam hal ini IgG serum dan IgA saliva) yang spesifik terhadap antigen Pac dari Streptococcus mutans, diamati dalam penelitian tersebut. Selain itu juga diamati efek protein rekombinan FliC pada kolonisasi S.mutans dan pembentukan lesi karies pada gigi molar hewan percobaan tikus. $^{8}$

Hasil penelitian tersebut menunjukkan bahwa antibodi IgG serum pada kelompok tikus yang diberi perlakuan berupa kombinasi vaksin DNA anti karies gigi (pGJA-P/VAX) $100 \mu \mathrm{g}+10 \mu \mathrm{g}$ protein rekombinan FliC dan kelompok yang diberi perlakuan berupa kombinasi vaksin DNA anti karies gigi ( $p G J A-P / V A X) 100 \mu \mathrm{g}+20$ $\mu$ g protein rekombinan FliC , mengalami peningkatan kadar rata-rata sebesar 5,2 kali dan 8,8 kali lebih besar secara berurutan, dibandingkan kelompok tikus yang diberi perlakuan vaksinasi DNA anti karies gigi ( $p G J A-P / V A X)$ tunggal. Sedangkan kadar IgA saliva juga menunjukkan peningkatan kadar rata-rata sebesar 4.1 kali dan 7,0 kali lebih besar secara berurutan pada kedua kelompok tersebut, dibandingkan kelompok tikus yang diberi perlakuan vaksinasi DNA anti karies gigi ( $p G J A-$ $P / N A X$ ) tunggal. Pembentukan koloni S.mutans dan skor total karies pada kedua kelompok tersebut juga dilaporkan secara bermakna lebih rendah dibandingkan kelompok tikus yang diberi perlakuan vaksinasi DNA anti karies gigi ( $p G J A-P / V A X)$ tunggal. Pembentukan lesi karies pada kedua kelompok tersebut juga dilaporkan mengalami penurunan rata-rata sebesar 41,1\% dan 47,0\% secara berurutan dibandingkan kelompok tikus yang diberi perlakuan vaksinasi DNA anti karies gigi ( $p G J A-$ $P / V A X)$ tunggal dengan tingkat penurunan lesi karies hanya mencapai $18,3 \% .^{8}$

\section{PEMBAHASAN}

Peningkatan kadar antibodi IgG serum dan IgA saliva yang lebih besar secara bermakna pada kelompok tikus yang diberi perlakuan berupa kombinasi vaksin DNA anti karies gigi ( $p G J A-P / V A X) 100 \mu \mathrm{g}+10 \mu \mathrm{g}$ protein rekombinan FliC dan kelompok tikus yang diberi perlakuan berupa kombinasi vaksin DNA anti karies gigi (pGJA-P/VAX) $100 \mu \mathrm{g}+20 \mu \mathrm{g}$ protein rekombinan FliC, dibandingkan kelompok tikus yang hanya diberi perlakuan vaksinasi DNA anti karies gigi ( $p G J A-P / V A X)$ tunggal dalam penelitian Shi W dkk pada tahun 2012, telah membuktikan bahwa protein rekombinan FliC (flagellin) sebagai ajuvan mukosa pada vaksinasi karies gigi melalui jalur intra nasal, mampu meningkatkan imunogenitas vaksin DNA anti karies gigi ( $p G J A-P / V A X)$. Peningkatan imunogenitas vaksin DNA anti karies gigi pada penelitian tersebut, didasarkan pada peningkatan respon imun IgG serum dan IgA saliva terhadap antigen $P a c$ dari S.mutans dalam vaksin DNA anti karies gigi, yang secara nyata bermanifestasi dalam bentuk peningkatan kadar IgG serum dan IgA saliva sebagai antibodi spesifik terhadap antigen Pac dari S.mutans dalam vaksin DNA anti karies gigi. ${ }^{8}$

Peningkatan kadar antibodi IgG serum dan IgA saliva berkaitan erat dengan pengurangan jumlah koloni bakteri kariogenik S.mutans serta pengurangan lesi karies gigi pada permukaan gigi hewan percobaan tikus sehingga berdampak memberi perlindungan terhadap karies gigi. Pengurangan jumlah koloni S.mutans terkait peningkatan kadar antibodi IgA saliva, terjadi melalui mekanisme hambatan perlekatan sucrose-independent dan sucrose-dependent dari bakteri kariogenik S.mutans ke permukaan gigi dan selanjutnya mengurangi produk metabolit berbahaya dari bakteri (dalam hal ini terutama asam laktat) yang berpengaruh terhadap terjadinya demineralisasi permukaan email gigi hingga terbentuknya lubang (kavitas) pada proses karies gigi. ${ }^{8,15}$ Hambatan kolonisasi S.mutans dan pembentukan karies selanjutnya juga dimungkinkan terjadi karena IgA saliva berperan sebagai aglutinin spesifik terhadap reseptor permukaan bakteri S.mutans. ${ }^{12}$

Peningkatan kadar antibodi IgG serum terkait dengan pengurangan jumlah koloni S.mutans serta pengurangan lesi karies gigi pada permukaan gigi hewan percobaan tikus juga berperan memberi perlindungan 
pejamu terhadap karies gigi karena antibodi IgG memiliki efek hambatan pada perlekatan ke permukaan gigi, glukosil tranferase dan produksi asam sehingga menghambat keberadaan dan metabolisme bakteri kariogenik S.mutans. Antibodi IgG sebagai salah satu komponen antibodi serum, dapat terbawa masuk ke dalam rongga mulut melalui cairan saku gusi (gingival crevicular fluid), transudat mukosa dan ultrafiltrasi melalui kelenjar ludah, untuk selanjutnya berperan dalam proteksi terhadap karies gigi. Antibodi IgG serum yang bertanggung jawab pada respon imun humoral juga diketahui memiliki fungsi untuk mengaktifkan sistem komplemen, opsonisasi dan peningkatan aktivitas fagositosis hingga lisis bakteri. ${ }^{16,17}$ Pengurangan jumlah kolonisasi bakteri $S$ mutans pada gigi hewan percobaan tikus yang selanjutnya berpengaruh terhadap pengurangan lesi karies yang terbentuk di permukaan gigi tikus, tampaknya sejalan dengan hasil penelitian sebelumnya yang menyatakan bahwa penurunan jumlah kolonisasi bakteri S.mutans dalam rongga mulut berkorelasi dengan pengurangan lesi karies yang terbentuk di bagian fissure dan permukaan halus gigi. ${ }^{18}$ Penggunaan ajuvan mukosa berupa protein rekombinan FliC (flagellin) yang menyertai vaksin DNA anti karies gigi pada penelitian Shi W,dkk pada tahun 2012 juga menunjukkan imunogenitas yang lebih baik bila dibandingkan penelitian lainnya oleh Xu,dkk pada tahun 2007 terhadap vaksin DNA anti karies gigi yang dikombinasi dengan ajuvan mukosa jenis chitosan dan bupivacaine melalui jalur intra nasal. ${ }^{11}$

\section{RINGKASAN}

Protein rekombinan FliC (flagellin) yang berasal dari Salmonella enterica, memiliki potensi yang menjanjikan sebagai ajuvan mukosa pada vaksin DNA anti karies gigi (vaksin $p G J A-P / V A X$ ). Penggunaan kombinasi protein rekombinan FliC (flagellin) dengan vaksin DNA anti karies gigi melalui jalur vaksinasi intra nasal pada hewan percobaan tikus terbukti mampu meningkatkan imunogenitas dari vaksin DNA anti karies gigi untuk menginduksi respon imum sistemik (meningkatkan kadar IgG serum spesifik) dan respon imun mukosa (meningkatkan kadar IgA saliva spesifik) terhadap antigen Pac dari Streptococcus mutans sehingga memberi perlindungan yang lebih baik terhadap karies gigi. Induksi peningkatan kadar IgG serum spesifik dan IgA saliva spesifik terhadap antigen Pac dari Streptococcus mutans oleh protein rekombinan FliC pada vaksin DNA anti karies gigi, memiliki korelasi positif dengan penurunan jumlah bakteri Streptococcus mutans serta pengurangan lesi karies gigi.

\section{DAFTAR PUSTAKA}

1. Creanor S. Essential clinical oral biology.UK:John Wiley \& Sons Ltd.2016:24-33,100-104,145-149.

2. Duzgunes N. Medical microbiology and immunology for dentistry.Chicago: Quintessence Publishing Co Inc.2016: 9-11,15-22,36-38.

3. Bao R, Yang JY, Sun Y, Zhou DH, Yang Y, Li YM, Cao
Y.Flagellin-Pac fusion protein inhibits progresion of established caries. J Dent Res.2015;94(7):955-960.

4. Shanmugam KT, Masthan KMK, Balachander N, Jimson S, Sarangarajan R. Dental caries vaccine-a possible option. Journal of Clinical and Diagnostic Research.2013;7(6): 1250-1253.

5. Malavika J, Hiremath SS, Das M, Musareth A, Arora P. Dental caries vaccine : a review. International Journal of Oral Health and Medical Research.2016;3(4):104-108.

6. Shivakumar KM, Vidya SK ,Chandu GN. Dental caries vaccine.Indian J Res.2009;20:99-106.

7. Baratawidjaja KG. Imunologi dasar. Jakarta:Badan Penerbit Fakultas Kedokteran Universitas Indonesia.2014:468-506.

8. Shi W, Li YH, Liu F, Yang JY, Zhou DH, Chen QY, Zhang Y. Flagellin enhanced saliva IgA response and protection of anti-caries DNA vaccine. J Dent Res.2012;91(3):249254.

9. Dalai DR, Bhaskar DJ, Agali C, Gupta V, Sigh N. Caries vaccine. TMU J Dent.2015;2(2):48-51.

10. Radji M. Imunologi \& Virulogi. Cetakan kedua. Jakarta: PT Isfi Penerbitan.2015;29-45,65-78, 93-97.

11. Xu QA, Yu F, Fan MW, Bian Z, Chen Z, Peng B. Protective efficacy of a targeted anti caries DNA plasmid against cariogenic bacteria infections.2007.J Vaccine;25:1191-1195.

12. Gambhir RS, Singh S, Singh G, Singh R, Nanda T, Kakar $\mathrm{H}$. Vaccine against dental caries-an urgent need. $J$ Vaccines Vaccine.2012;3(2):1-7.

13. Xu QA, Yu F, Fan MW, Bian Z, Chen Z,Fan B. Immunogenicity and persistence of a targeted anti caries DNA vaccine.2006. J Dent Res;85(10):915-818.

14. Liu u QA, Jin J, Li YH, Jia R, Guo JH. Mucosal ans systemic immunization with targeted fusion anti caries DNA plasmid in young rat. J Vaccine.2009;29:2940-2947.

15. Sujith R, Naik S, Janavathi, Rajanikant P. Carries vaccinea review. Indian Journal of Mednodent and Allied Sciences.2014;2(2):198-203.

16. Setia S, Gambhir RS, Kapoor V. Immunology in prevention of dental caries. Universal Research Journal of Dentistry.2012;2(2):58-63.

17. Fabian TK, Hermann P, Beck A, Fejerdy P, Fabian G. Salivary defence proteins:their network and role in innate and acquired oral immunity. Int J Mol Sci.2012;13(4):42954320.

18. Guggenheim B, Schmid R, Aeschlimann JM, Berrocal R, Neeser JR. Powdered milk micccllar casein prevents oral colonization by Streptococcus sobrinus and dental caries in rats: a basis for the caries protective effect of dairy products J Car Res.1999;33: 446-454. 